Environmental Restoration Division

\title{
Annual Summary of the Contents of the Oak Ridge Environmental Information System Data Base
}

Date Issued-June 1994

\author{
Prepared by \\ Oak Ridge Environmental Information System \\ Oak Ridge National Laboratory \\ Prepared for \\ U.S. Department of Energy \\ Office of Environmental Restoration and Waste Management \\ under budget and reporting code EW 20

\section{MARTIN MARIETTA ENERGY SYSTEMS, INC.} \\ managing the \\ Paducah Gaseous Diffusion Plant \\ Portsmouth Gaseous Diffusion Plant \\ under contract DE-AC05-76OR00001 \\ for the \\ U.S. DEPARTMENT OF ENERGY \\ under contract DE-AC05-84OR21400
}

Oak Ridge K-25 Site

Oak Ridge Y-12 Plant

Oak Ridge National Laboratory under contract DE-AC05-84OR21400

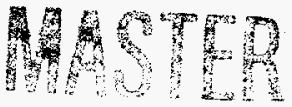




\title{
Oak Ridge Environmental Information System (OREIS) Team
}

\author{
R. A. McCord \\ D. D. Herr \\ R. C. Durfee \\ M. L. Land \\ F. E. Monroe \\ R. J. Olson \\ J. K. Thomas \\ E. P. Tinnel
}

Author Affiliations

R. A. McCord and R. J. Olson are members of the Environmental Sciences Division, R. C. Durfee and E. P. Tinnel are members of the Computing Applications Division, D. D. Herr and F. E. Monroe are members of the Computing and Telecommunications Services, and M. L. Land and J. K. Thomas are members of the Health. Sciences Research Division, Martin Marietta Energy Systems, Inc. 


\section{DISCLAIMER}

This report was prepared as an account of work sponsored by an agency of the United States Government. Neither the United States Government nor any agency thereof, nor any of their employees, make any warranty, express or implied, or assumes any legal liability or responsibility for the accuracy, completeness, or usefulness of any information, apparatus, product, or process disclosed, or represents that its use would not infringe privately owned rights. Reference herein to any specific commercial product, process, or service by trade name, trademark, manufacturer, or otherwise does not necessarily constitute or imply its endorsement, recommendation, or favoring by the United States Government or any agency thereof. The views and opinions of authors expressed herein do not necessarily state or reflect those of the United States Government or any agency thereof. 


\section{DISCLAIMER}

Portions of this document may be illegible in electronic image products. Images are produced from the best available original document. 


\section{CONTENTS}

FIGURES $\ldots \ldots \ldots \ldots \ldots \ldots \ldots \ldots \ldots \ldots \ldots \ldots \ldots \ldots \ldots$

TABLES $\ldots \ldots \ldots \ldots \ldots \ldots \ldots \ldots \ldots \ldots \ldots \ldots \ldots \ldots \ldots$

ABBREVIATIONS AND ACRONYMS $\ldots \ldots \ldots \ldots \ldots \ldots \ldots \ldots \ldots$ vii

EXECUTIVE SUMMARY $\ldots \ldots \ldots \ldots \ldots \ldots \ldots \ldots \ldots \ldots \ldots \ldots \ldots \ldots$

1. PURPOSE AND SCOPE $\ldots \ldots \ldots \ldots \ldots \ldots \ldots \ldots \ldots \ldots \ldots \ldots \ldots \ldots \ldots$

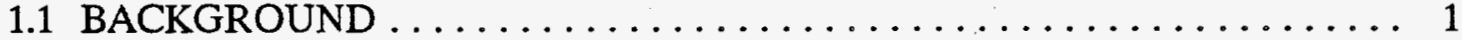

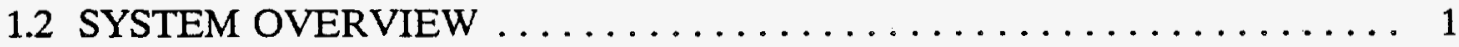

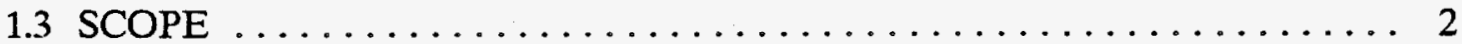

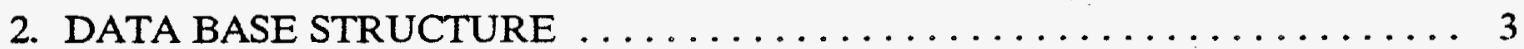

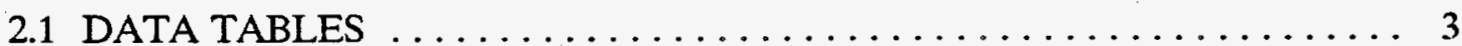

2.1.1 Descriptor Data Tables . . . . . . . . . . . . . . 3

2.1.2 Measurement Data Tables .................... 4

2.1.3 Reference Data Tables ....................... 7

2.2 CHANGE DATA TABLES . . . . . . . . . . . . . . . . . 7

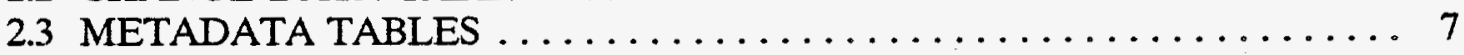

2.4 ADMINISTRATIVE INFORMATION TABLES $\ldots \ldots \ldots \ldots \ldots \ldots \ldots \ldots$

2.5 GEOGRAPHIC DATA $\ldots \ldots \ldots \ldots \ldots \ldots \ldots \ldots \ldots \ldots \ldots \ldots \ldots \ldots$

2.6 NONCOMPUTERIZED RECORDS $\ldots \ldots \ldots \ldots \ldots \ldots \ldots \ldots \ldots$

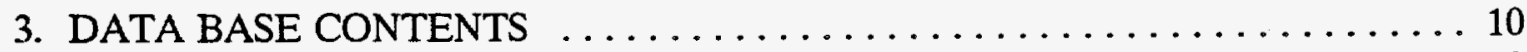

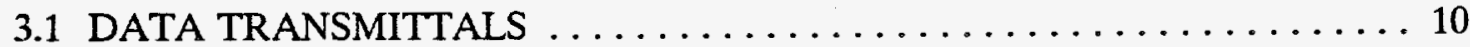

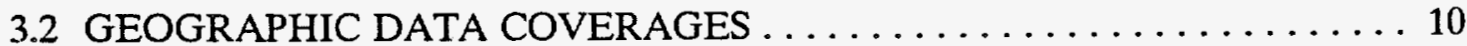

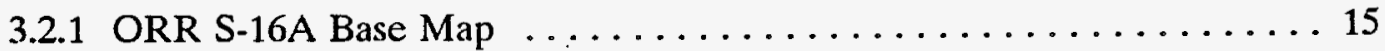

3.2 .2 Operable Unit Boundaries . . . . . . . . . . . . . . . 15

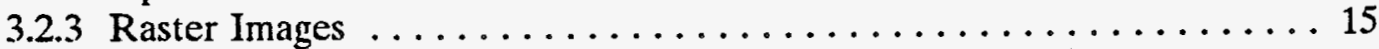

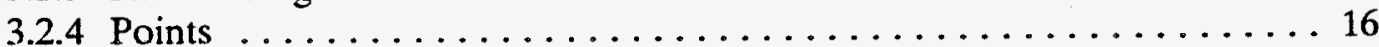

4. REFERENCES .............................. 19

APPENDIX A. Oak Ridge Environmental Information System

Geographic Data Base

APPENDIX B. Environmental Restoration Projects in the OREIS

PROJECT Table 


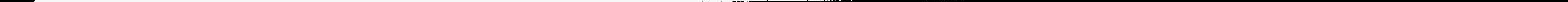




\section{FIGURES}

1. OREIS Data Model $\ldots \ldots \ldots \ldots \ldots \ldots \ldots \ldots \ldots \ldots \ldots \ldots \ldots$

2. Index Map of the Raster Image Coverages $\ldots \ldots \ldots \ldots \ldots \ldots$

3. Index Map of the Sampling Station Locations $\ldots \ldots \ldots \ldots \ldots \ldots \ldots \ldots \ldots \ldots$

\section{TABLES}

1. Tables and other types of information within OREIS organized by data type $\ldots \ldots 7$

2. Number of rows within OREIS tables organized by project $\ldots \ldots \ldots \ldots \ldots$

3. Number of rows within OREIS metadata and codes tables $\ldots \ldots \ldots \ldots \ldots$

4. Dates associated with data packages transmitted to OREIS $\ldots \ldots \ldots \ldots \ldots$

5. Descriptions of data packages transmitted to OREIS $\ldots \ldots \ldots \ldots \ldots \ldots$

6. Descriptions of the OREIS raster images for the ORR sites $\ldots \ldots \ldots \ldots \ldots \ldots$ 


\section{ABBREVIATIONS AND ACRONYMS}

AGL

CAS

DOE

DOE-ORO

Energy Systems

EPA

ER

FFA

GIS

IFF

OREIS

ORNL

ORR

OU

RDBMS

RI

TDEC

TOA

TVA

USGS

WAG above ground level

Chemical Abstracts Service

U.S. Department of Energy

DOE Oak Ridge Operations

Martin Marietta Energy Systems, Inc.

Environmental Protection Agency

Environmental Restoration

Federal Facility Agreement

Geographic Information System

Interchange File Format

Oak Ridge Environmental Information System

Oak Ridge National Laboratory

Oak Ridge Reservation

Operable Unit

Relational Data Base Management System

Remedial Investigation

Tennessee Department of Environment and Conservation

Tennessee Oversight Agreement

Tennessee Valley Authority

U.S. Geological Survey

Waste Area Grouping 


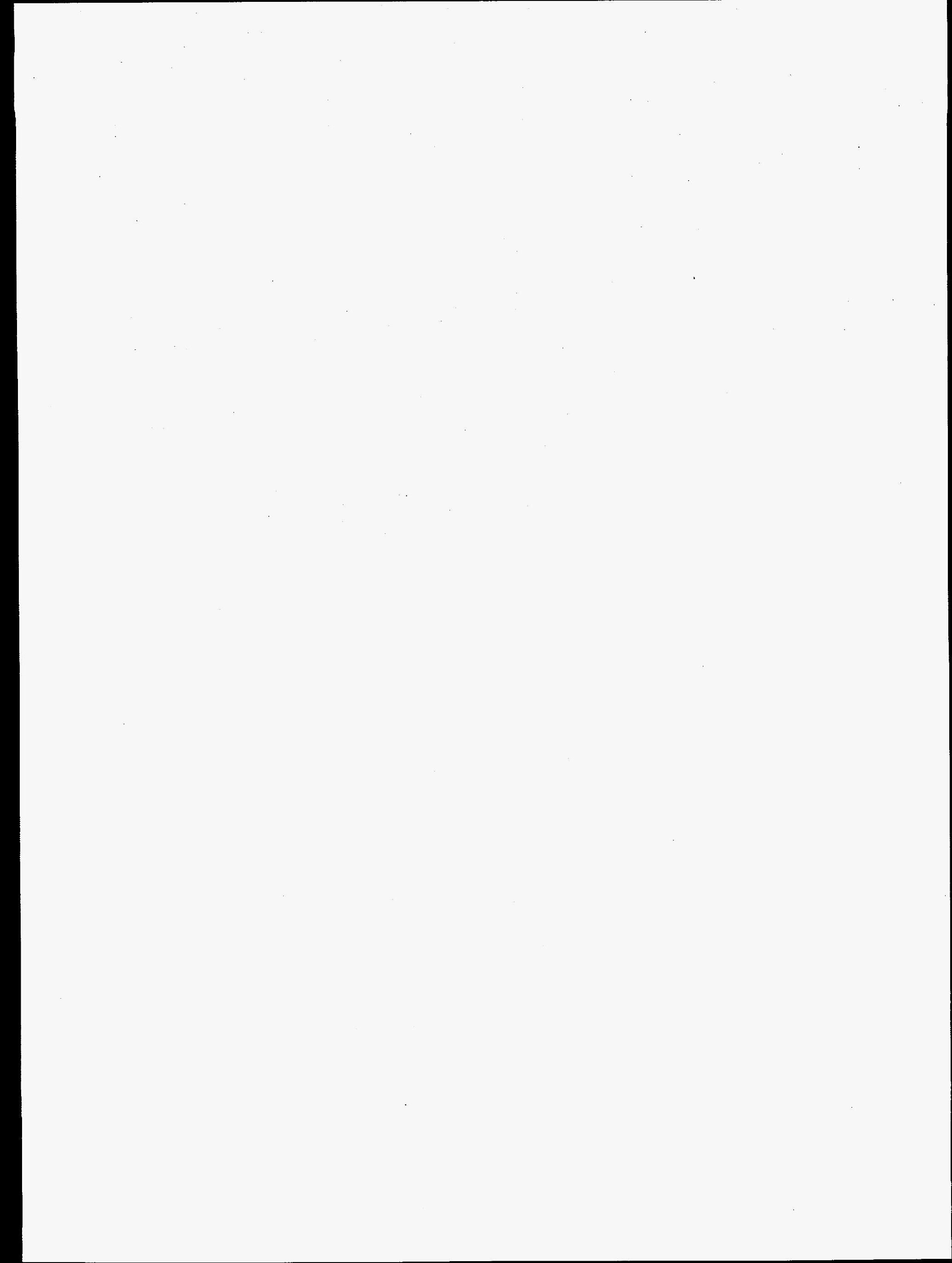




\section{TRADEMARKS}

Reference to the following commercial products, by trade name, trademark, manufacturer, or otherwise, does not necessarily constitute or imply an endorsement or recommendation.

ARC/INFO and ARC View are trademarks of the Environmental Systems Research Institute, Redlands, Calif. INFO is a trademark of Henco Software, Inc. ERDAS is a trademark of ERDAS, Inc. ORACLE, SQL*Plus, SQL*Forms, CASE*Design, and CASE*Dictionary are trademarks of the ORACLE Corporation. SAS, SAS/ACCESS, and SAS/INSIGHT are trademarks of the SAS Institute Inc., Carey, North Carolina. UNIX is a trademark of AT\&T. 



\section{EXECUTIVE SUMMARY}

The data base of the Oak Ridge Environmental Information System (OREIS) contains data of known quality that can be accessed by OREIS users. OREIS meets data management/ access requirements for environmental data as specified in the Federal Facility Agreement for the Oak Ridge Reservation and the State Oversight Agreement between the State of Tennessee and the Department of Energy. The types of environmental data within OREIS include measurement data from the following environmental disciplines: groundwater, surface water, sediment, soils, air, and biota. In addition to measurement data, the OREIS data base contains extensive descriptive and qualifier metadata to help define data quality and to enable end users to analyze the appropriateness of data for their purposes. Another important aspect of measurement data is their spatial context; OREIS maintains a comprehensive library of geographic data and tools to analyze and display spatial relationships of the data.

As of November 1993 , the OREIS data base consists of approximately 100,000 records associated with three environmental restoration projects along with coordinate data and background map data. The data base also contains 2700 supporting codes and other reference data records. Geographic data include the S-16A base map for the Oak Ridge Reservation, boundaries for operable units, and high-resolution raster images for each of the sites. 


\section{PURPOSE AND SCOPE}

\subsection{BACKGROUND}

The Oak Ridge Environmental Information System (OREIS) is a centralized computer system that meets data management/access requirements for environmental data as specified in the Federal Facility Agreement for the Oak Ridge Reservation (FFA) (DOE 1992a) and the State Oversight Agreement between the State of Tennessee and the Department of Energy (TOA) (TOA 1991). OREIS is mandated by DOE Oak Ridge Operations (DOE-ORO) Environmental Restoration (ER) Division to fulfill the environmental data requirements prescribed in both the FFA and the TOA and is tasked by the ER Division of Martin Marietta Energy Systems, Inc. (Energy Systems) to support environmental data management activities for the facilities managed by Energy Systems as they relate to the consolidated data base. These facilities include the three Oak Ridge Reservation (ORR) facilities [Oak Ridge National Laboratory (ORNL), the Oak Ridge Y-12 Plant, and the Oak Ridge K-25 Site] and the gaseous diffusion plants located at Paducah, Kentucky, and Portsmouth, Ohio.

This report provides OREIS users with a general overview of the contents of the OREIS data base as of November 1993. The design and development of the OREIS system was initiated in 1991. In 1992 and 1993, data associated with six ER projects were transmitted to OREIS, processed, and provided to regulators as specified in the FFA and TOA. The processing and review of these data were used as an integral part of the developmental phase of OREIS to verify the completeness and efficiency of the OREIS data base structure and processing and review procedures. As OREIS moves into the implementation phase in 1994, more emphasis will be placed on the routine processing and review of data transmitted to OREIS.

\subsection{SYSTEM OVERVIEW}

The Data Management Plan for the Oak Ridge Environmental Information System (in press), provides a detailed description of the OREIS objectives, data base structure, and supporting components. In addition to the data base, components of OREIS include the information system, the procedures, and the data management staff. The data base component compiles data of known quality, maintains the integrity of the data base, and provides access to the data base. The information system component maintains the computer system, provides application tools (e.g., graphs, statistics, maps, and user interface and query menus), and provides primary user support. The procedures component documents the development and operation of the system; guides the processing, reviewing, and reporting of data; and informs OREIS users on how to access and use data in OREIS.

The OREIS data base contains a wide variety of environmental measurement data and associated geographic data. The data base accommodates diverse data from many sources that are brought together to determine baseline values, examine long-term trends, or produce composite products as needed by environmental restoration or other programs. Remedial investigations, which generate the majority of environmental restoration data, are just one 
part of the overall environmental program supported by the OREIS data base for managing facilities and waste, conducting restoration activities, performing decontamination/ decommissioning, monitoring for compliance and surveillance, and conducting risk assessments.

The environmental measurement data base includes data that describe projects; locate sampling stations; specify sampling events; describe boreholes and their associated lithology; provide well, borehole, and tank construction and status information; represent field measurements, including data collected on plant and animal samples; and represent laboratory analysis results. Typical remedial investigations of waste disposal areas include drilling wells to sample groundwater and drilling boreholes to sample soils. The water and soil samples are analyzed for radiological, chemical, and physical properties. Laboratory analyses determine levels of volatile organic compounds, metals, pesticides, and other compounds. Groundwater levels, surface water flows, and lithology characterizations are used to study groundwater hydrology.

In addition to measurement data, the OREIS data base contains extensive descriptive and qualifier metadata to help define data quality and to enable other end users to analyze the appropriateness of data for their purposes. Another important aspect of measurement data is their spatial context; OREIS maintains a comprehensive library of geographic data and tools to analyze and display spatial relationships of the data. OREIS serves as the repository for the ORR S-16A base map, the operable unit (OU) boundaries, image and remote sensing data from the ER Aerial Survey Program, and other spatial data bases for the ORR and specific sites.

OREIS runs on SUN workstations in a UNIX operating environment. A central data server maintains the master data base and software that can be accessed from workstations or personal computers via a network connection. Software consists of commercially available application tools including a Relational Data Base Management System (RDBMS) (ORACLE) linked with a statistical analysis and display system (SAS) and a geographic information system (GIS) (ARC/INFO). Each system provides specific "user-friendly" tools oriented toward user data retrieval, analysis, and display, including Oracle Data Browser, SAS/ASSIST, SAS/INSIGHT, and ARC View. The OREIS User Interface provides an integrated way to access the application tools and common data subsets. For example, Oracle Data Browser may be used to create a user defined view of selected data which then can be processed with either SAS/INSIGHT or ARC View through the OREIS User Interface. The capabilities and guidelines for accessing the data base with the tools will be described in an OREIS User's Guide now under development.

\subsection{SCOPE}

This report is the first annual snapshot of the contents of the OREIS data base. The data base expands as ER projects are completed and data associated with regulatory reports are transmitted to OREIS. In addition, environmental compliance and surveillance monitoring data are routinely collected by environmental monitoring programs and will eventually be transmitted to OREIS. Geographic data are developed in support of various environmental programs within Energy Systems (e.g., environmentally sensitive areas and gamma radiation contours). As they are provided to OREIS, appropriate coverages are established for use with measurement data. Section 2 briefly reviews the data base structure; Sect. 3 summarizes the contents as of November 1993. 


\section{DATA BASE STRUCTURE}

This section reviews the OREIS data base structure, which consists of measurement and associated data in the ORACLE RDBMS and geographic data in the ARC/NFO GIS (Table 1). Section 2.1 describes the descriptor, measurement, and reference data tables. Section 2.2 describes the change data tables, which are companion tables to those in Sect. 2.1. and which document changes to records in these tables. Metadata tables are described in Sect. 2.3 and administrative tables in Sect. 2.4. Section 2.5 addresses geographic data. Noncomputerized information and records are discussed in Sect. 2.6. The tables and fields within each table are defined in more detail in the Data Management Plan for the Oak Ridge Environmental Information System (in press).

\subsection{DATA TABLES}

Environmental measurement data are contained in the set of data tables briefly described below. The tables are linked together in an RBDMS as shown in Fig. 1. An identical set of data tables is maintained in the ORACLE TRANS area and is used to process and review new data transmitted to OREIS. After data are authorized for release by the data generator, the data are moved from the TRANS area to tables in the OREIS area and are available to OREIS users.

\subsubsection{Descriptor Data Tables}

The OREIS descriptor data tables (Table 1) include BORECONS, LITHOLOGY, LOCATION, PROJECT, STATION, TANK, WELL, and WELLCONS. Within the descriptor tables, there is usually one record per project, sampling site, well, borehole, or tank that characterizes that object.

ER projects are initiated to characterize a waste disposal or other contaminated area and to determine the cleanup needs and most appropriate action(s), which may be to take no actions at all. The PROJECT table describes the ER projects as defined in the Oak Ridge Reservation Site Management Plan for the Environmental Restoration Program (DOE 1993b).

The STATION table contains the station name assigned by a project to each sampling or monitoring station. Stations can be wells, boreholes, tanks, cores, soil pits, or stream sampling points. The LOCATION table defines the geographic coordinates and elevation of unique points or stations. Any point in the LOCATION table can have multiple station names in the STATION table, either within a project or between projects.

The WELL table contains essential information for any well, borehole, or other hole in the ground. The WELLCONS table includes more detailed well construction and development information and the BORECONS table includes borehole construction information. A borehole can be converted to a well and, therefore, have records in both the BORECONS and WELLCONS tables. The LITHOLOGY table includes the lithologic description and a classification of cuttings and cores taken from boreholes. The TANK table (currently under development) will define the size, depth, contents, and other characteristics of tanks. 


\subsubsection{Measurement Data Tables}

The OREIS measurement data tables (see Table 1) include BIOTA, FLD_EVENT, FLD_MEAS, FLD_SMP, LAB_MEAS, LAB_SMP, QC_FLD_SMP, and ASSOCIÄTE_QC. They usually contain multiple records per sampling station representing periodic sampling and/or measurement results for multiple parameters.

The BIOTA table contains data from measurements of plant and animal materials. Characteristics measured may include weight, length, or radioactivity level. Measurements are often summarized as averages.

The FLD_EVENT table identifies a field measurement event that does not involve collecting a sample. The date of the measurement, the type of measurement, and the methods used to collect a measurement are included in this table. The FLD_MEAS table contains time of the measurement, the parameter being measured, and the results of the field measurement. Typical field measurements include surface flow, meteorology, and piezometer readings. Often, measurements may be summarized from a continuous recorder to represent averages or other statistics.

The FLD_SMP table describes the samples that are collected in the field. The date and time that the samples are collected, depth of the sample, sample media, methods used to collect the sample, and sample preparation are included in this table. Sample media include groundwater, surface water, soil, air, and biological organisms. The project-assigned sample identifier is stored in this table. Field measurement data taken during the sample collection process are entered in the FLD_EVENT and FLD_MEAS tables.

The LAB_SMP table describes samples that are submitted for laboratory analysis. There must be an entry in the FLD SMP table for each sample processed by the laboratory. The identifier assigned by the analytical laboratory is stored in this table. Attributes include laboratory identifiers, the date analyzed, and the type of analysis. The LAB_MEAS table contains the results from laboratory analyses, including the parameter measured and associated data qualifiers, units of measure, and method of analysis. Each sample may be analyzed for a variety of parameters, with the results for each parameter stored as separate records in the LAB_MEAS table. The LAB_MEAS table may become the largest data table in OREIS. Parameters measured-identified by Chemical Abstracts Service (CAS) number when possible-can be one of the many analysis types (e.g., metals, anions, organics, inorganics, pesticides, radionuclides, or other compounds).

Field quality control samples, including trip blanks, field blanks, and equipment rinsates, are routinely collected, and the results from these samples are associated with several regular samples. The QC sample information is entered in the QC_FLD_SMP table. This table is identical to the FLD_SMP table except there are no station identifiers. The ASSOCIATE_QC table links the QC samples to their appropriate laboratory samples. 
Table 1. Tables and other types of information within OREIS organized by data type

\begin{tabular}{|c|c|c|c|}
\hline Data type & System & Data table & Change data table \\
\hline \multirow[t]{8}{*}{ Descriptor } & ORACLE & PROJECT & PROJECT_XACTION \\
\hline & ORACLE & LOCATION & LOCATION_XACTION \\
\hline & ORACLE & STATION & STATION_XACTION \\
\hline & ORACLE & WELL & WELL_XACTION \\
\hline & ORACLE & WELLCONS ${ }^{a}$ & WELLCONS_XACTION \\
\hline & ORACLE & BORECONS ${ }^{a}$ & BORECONS_XACTION \\
\hline & ORACLE & LITHOLOGY $^{a}$ & LITHOLOGY_XACTION \\
\hline & ORACLE & TANK $^{a}$ & TANK_XACTION \\
\hline \multirow[t]{8}{*}{ Measurement } & ORACLE & FLD_EVENT & FLD_EVENT_XACTION \\
\hline & ORACLE & FLD_MEAS & FLD_MEAS_XACTION \\
\hline & ORACLE & BIOTA $^{a}$ & BIOTA_XACTION \\
\hline & ORACLE & FLD_SMP & FLD_SMP_XACTION \\
\hline & ORACLE & LAB_SMP & LAB_SMP_XACTION \\
\hline & ORACLE & LAB_MEAS & LAB_MEAS_XACTION \\
\hline & ORACLE & QC_FLD_SMP & QC_FLD_SMP_XACTION \\
\hline & ORACLE & ASSOCIATE_QC & ASSOCIATE_QC_XACTION \\
\hline \multirow[t]{5}{*}{ Reference } & ORACLE & CODE & \\
\hline & ORACLE & PARAMETER & \\
\hline & ORACLE & METHOD & \\
\hline & ORACLE & METHOD_TYPE & \\
\hline & ORACLE & CRITERIA & \\
\hline \multirow[t]{3}{*}{ Metadata } & ORACLE & DATASET & \\
\hline & ORACLE & TRANSMITTAL & \\
\hline & ORACLE & ALIAS_SOURCE & \\
\hline \multirow[t]{2}{*}{ Administrative } & ORACLE & TRANSACTION ${ }^{a}$ & \\
\hline & ORACLE & CONTACT & \\
\hline \multirow[t]{4}{*}{ Geographic } & ARC/INFO & Base data (S-16A) & \\
\hline & ARC/INFO & $\begin{array}{l}\text { Operable Unit } \\
\text { Boundaries }\end{array}$ & \\
\hline & ARC/INFO & Raster Images & \\
\hline & ARC/INFO & Sampling locations & \\
\hline \multirow[t]{2}{*}{ Records } & File Cabinet & Back-up media & \\
\hline & File Cabinet & Project records & \\
\hline
\end{tabular}

a Tables currently under development. 


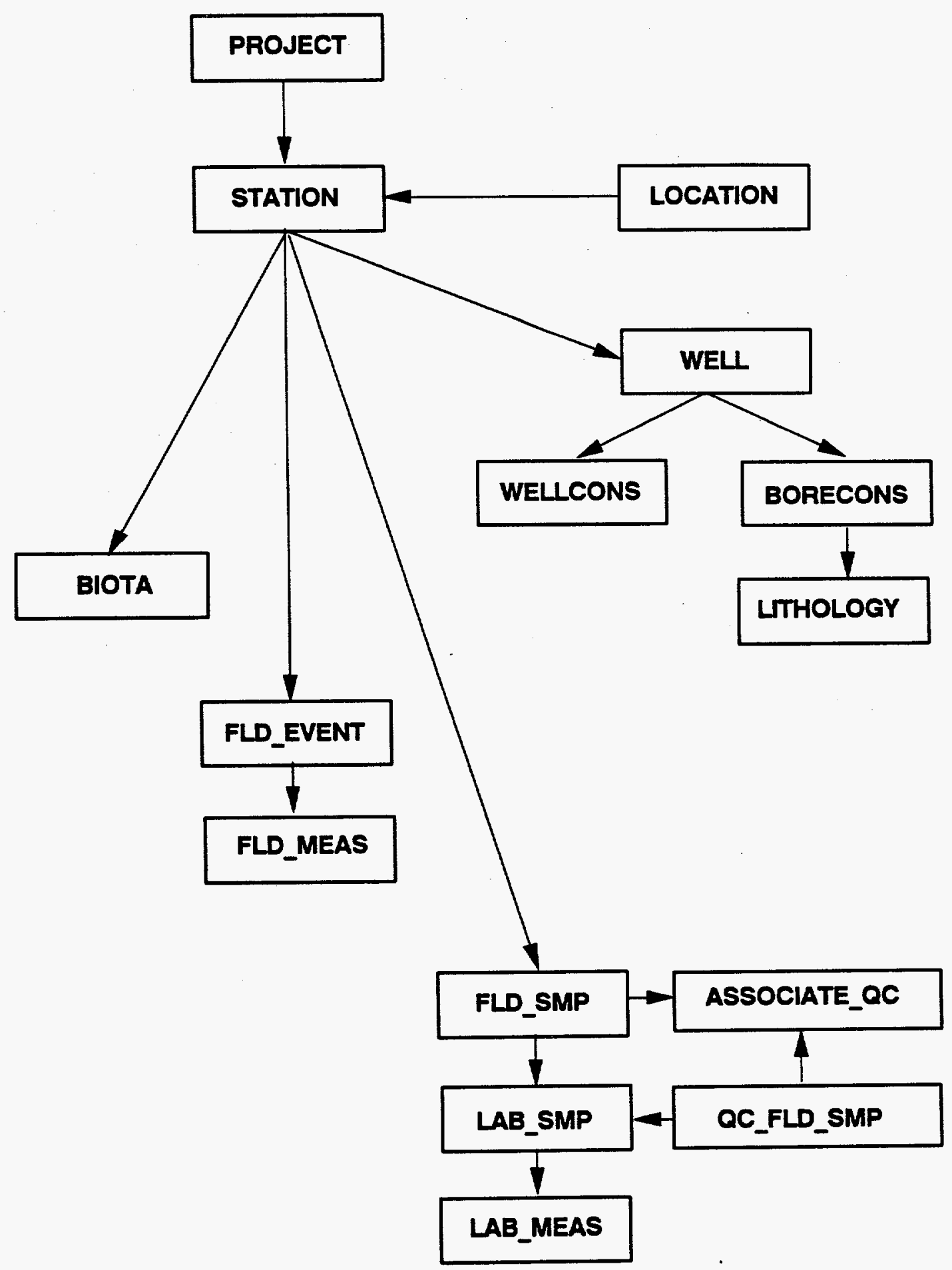

Fig. 1. Oak Ridge Environmental Information System data model. 


\subsubsection{Reference Data Tables}

These are tables that provide additional information when linked to the measurement data tables. The reference tables include CRITERIA, CODE, PARAMETER, METHOD, and METHOD_TYPE. The CRITERIA table contains a set of regulatory values that can be compared to monitoring results on a parameter-by-parameter basis for specific sites to indicate whether the monitoring results have exceeded various regulatory levels. In some cases, additional information is provided, including such items as alias names, codes, and regulatory references.

The CODE table contains a list of codes used in specific OREIS fields and the corresponding description of the code values. The PARAMETER table contains a 40-character descriptive name, compound group, and CAS chemical compound numbers or pseudo-CAS codes for all the parameters referenced in the BIOTA, CRITERIA, FLD_MEAS, and LAB_MEAS data tables. The selection and assignment of CAS numbers and descriptive names is made by the Energy Systems Common Lab Practices Performance Improvement Process committee, including assigning official pseudo-CAS numbers for compounds or measurements that do not have CAS numbers.

The METHOD table contains codes, descriptions, and references for all the standard analytical methods. The selection and assignment of method codes and descriptive names is performed by the Energy Systems Common Lab Practices Performance Improvement Process committee. If a nonstandard method is used, it may be entered in a separate field in the LAB_MEAS table with associated comments as appropriate. The METHOD_TYPE table defines the typical parameters that each method can determine.

\subsection{CHANGE DATA TABLES}

The change data tables store all past versions of OREIS data records and provide an audit trail of changes and deletions made to the data base. All data tables have a field, D_MODIFIED, to indicate whether a record has been changed. An audit trail is required to track the changes, updates, and deletions made to the OREIS data base, including the date and reasons for a change. Tracking changes to data and saving original data are accomplished by transferring out-of-date data to a companion set of tables that are named according to the convention of concatenating the original table name with "XACTION" (e.g., PROJECT XACTION). Other tables that have_XACTION tables include LOCATION, WELL, WELLCONS, BORECONS, LITHOLOGY, TANK, BIOTA, FLD_EVENT, FLD MEAS, FLD SMP, LAB SMP, LAB MEAS, CRITERIA, ASSOCIATE_QC, and QC_F FL_SMP. These are listed in a separate column in Table 1, adjacent to their companion table.

\subsection{METADATA TABLES}

Metadata are the information about the data stored in the data base. This section describes the data dictionary tables that define data tables and fields and the data processing tables that document the contents and processing of the data before it is moved into data tables. 
The OREIS tables are described in the ORACLE system table ALL_TABLES. Fields in the various OREIS tables are defined in the ORACLE system table ALL_TAB_COLUMNS, with supplementary information in the OREIS DATA_DICT table.

Data are often transmitted to OREIS as a unit such as a SAS data set on a diskette or magnetic tape. The DATASET table contains a description of why and how data were collected, any processing that was done by the data generators, the original data format, and any additional supporting documentation that is available. Information for this table is supplied by the data generator. If data are updated by periodically transmitting new data sets (e.g., environmental monitoring data), then each new set of data may refer to the original metadata description in the DATASET table.

The TRANSMITTAL table describes the source of a data transmittal; the dates transmitted to OREIS; and the type of processing, reformatting, and checking performed by OREIS staff to convert each record to meet OREIS conventions and standards. Information in this table is compiled by the OREIS staff during data processing. The TRANS_ID is the OREIS-assigned transmittal number that links records in various tables to the TRANSMITTAL table.

Because the OREIS data base consists of data from different sources, similar variables (e.g., temperature) often are assigned different names or units of measure, or were measured using different methods. The ALIAS_SOURCE table documents how the data source recorded and supplied data to OREIS and indicates the subsequent changes that were performed by OREIS to create internal consistency within the OREIS data base. The ALIAS_SOURCE table may contain several entries for a single OREIS field in a data table.

\subsection{ADMINISTRATIVE INFORMATION TABLES}

The OREIS data base contains necessary administrative records to support the data base operations. Administrative information associated with creating, maintaining, and using the data base is important in tracking the data processing. OREIS logs transactions, maintains a contact network, and participates in the ER records management program.

The TRANSACTION table (under development) will provide a record of the individuals, date, action, and general description of the various activities associated with maintaining and using the data base. Most OREIS transactions need to be logged for future reference. These transactions include transmitting data to OREIS; updating data; modifying programs; backing up or restoring the system; requesting data, reports, or graphics; or releasing memoranda or reports.

As part of regulatory requirements, correspondence, laboratory notebooks, memoranda, chain-of-custody records, reports, and other pertinent records must be placed in a long-term storage facility with an inventory system to enable documents to be identified and retrieved. OREIS will use existing systems to the greatest extent possible both to index supporting documentary information and to archive those records generated within OREIS.

The CONTACT table contains names; phone numbers; and mail, electronic mail, and facsimile addresses of various data generators, data users, and others associated with OREIS. 


\subsection{GEOGRAPHIC DATA}

Understanding the spatial context and characteristics of environmental measurement data is essential to the correct use and interpretation of the measurements. Measurement data must be located geographically and related to other geographic information for spatial queries and analysis. This involves linking measurement data to their associated geographic attributes within a geographic information system (GIS) to define the location, extent, distribution, and other spatial relationships. The measurement data are sometimes referred to as thematic tabular data; the geographic data associated with base maps are often referred to as cartographic data.

Within OREIS, the geometry, cartographic attributes, and topology are stored in the ARC/INFO data base structures. The tabular data are stored in ORACLE and linked to ARC/INFO for spatial and logical queries and for spatial analysis. It is essential that equivalent identifiers (cartographic attributes) be stored in both ARC/INFO and ORACLE (the OREIS LOCATION table) to allow the two types of data to be correctly linked.

Base map data (S-16A), including planimetric features such as buildings, roads, streams, and topographic contours, are normally used as background layers to which other thematic variables are referenced. A three-level hierarchy is currently used in OREIS to reference geographic data. These levels specify: (1) a particular geographic data base, (2) a selected theme, and (3) the specific layer or coverage chosen.

In addition to vector data bases, raster files (e.g., digital images of aerial photographs) are created and stored as background color images on which to superimpose point and vector information. Remote sensing is a powerful tool for collecting spatial information that can be used directly or indirectly within environmental programs. Geo-rectified aerial photographs also provide a visual backdrop for displaying other GIS data.

\subsection{NONCOMPUTERIZED RECORDS}

In addition to electronic data within OREIS, there are many types of supporting information that are an integral part of the environmental data. Most of these records are maintained by the data generators or the records management centers at each site. OREIS will store pointers to photographs, maps, field books, laboratory books, etc., that identify the location of the materials and summarize their significance. OREIS will also set up and maintain a library of map files (official and working) for computer maps, base maps, engineering maps, aerial photographs, imagery, gamma maps, electromagnetic maps, and radar imagery. 


\section{DATA BASE CONTENTS}

After the first two years of development and limited operations, the OREIS data base contains approximately 100,000 records or rows in 20 tables in the ORACLE RDBMS (Table 2). These records were generated from processing data associated with three remedial investigations; in addition, three other data packages are being processed. Over 370,000 records from the six remedial investigations have been transferred to regulators as specified in the FFA. There are an additional 2700 codes and other metadata records in the OREIS data base (Table 3). The ARC/NFO system contains associated spatial data representing 23 layers in the S-16A base map, boundaries for OUs, raster images for each site, and point locations for 1177 sampling stations.

\subsection{DATA TRANSMITTALS}

The OREIS program accepted the first of seven data transmittals of ER data in early 1992 (Tables 4 and 5). Data associated with six ER reports have been processed and transmitted to the regulatory agencies (Table 4); data associated with the seventh (Background Soils Characterization Project) have been received but not processed. Table 4 lists two dates with some of the activities, indicating a second transmittal event. Table 5 briefly describes each of the data packages and its size, along with the TRANS_IDs assigned by the OREIS staff. The TRANS_ID is used internally to identify transmittals of data that are processed as a unit.

As indicated in Table 4, some of these data packages have been processed and reviewed to meet OREIS guidelines but have not received final authorization from the respective ER project data custodians for release of the data to OREIS users. The OREIS staff have worked with project staff in resolving data problems and acquiring metadata; however, because of changes in the OREIS data base (i.e., transfer to Version 2.0 in late 1993) and changes in data transmittal procedures, the final authorization has been delayed.

\subsection{GEOGRAPHIC DATA COVERAGES}

The geographic data bases currently available in the OREIS data base include:

- the S-16A map data base for the ORR,

- boundaries of OUs and ORNL waste area groupings for environmental restoration activities,

- boundaries of groundwater coordination areas,

- background raster images of aerial photographs for the three ORR installations, and

- locations of wells and other point features generated from ORACLE tables.

A number of additional geographic data bases have been received or developed by OREIS staff and several of these are being set up as OREIS coverages (e.g., environmentally sensitive areas and gamma radiation contours) to be available as conversions, quality assurance checks, and documentation are completed. 
Table 2. Number of rows within OREIS tables organized by project

\begin{tabular}{lrrrrrrrr}
\hline \multicolumn{1}{c}{ Projcct } & PROJECT & STATION & LOCATION & FLD_SMP & QC_FLD_SMP & ASSOCI-ATE_QC & LAB_SMP & LAB_MEAS \\
\hline CR OU 2 & 1 & 25 & 25 & 60 & 7 & 7 & 116 & 1,496 \\
K-1407 & 1 & 126 & 126 & 380 & & 456 & 7,937 \\
OU & 1 & 590 & 590 & 2,208 & & 3,096 & 68,571 \\
WAG 1 & 62 & 436 & 436 & & & & \\
Others & 65 & 1,177 & 1,177 & 2,646 & 7 & 7 & 3,668 & 78,004 \\
Total & & & & & & & & \\
\hline
\end{tabular}

Table 2 (continucd)

\begin{tabular}{|c|c|c|c|c|c|c|c|c|}
\hline Project & ITLD_EVENT & FLD_MEAS & WELL & WELLCONS & IJTHIOLOGY & BORECONS & BIO'А & Total \\
\hline CR OU 2 & & & & & & & & 1,737 \\
\hline $\begin{array}{l}\mathrm{K}-1407 \\
\mathrm{OU}\end{array}$ & & & 126 & & & & & 9,152 \\
\hline WAG 1 & & & 204 & & & & & 75,258 \\
\hline Total & 0 & $\mathbf{0}$ & 330 & $\mathbf{0}$ & 0 & 0 & $\mathbf{0}$ & 87,034 \\
\hline
\end{tabular}


Table 3. Number of rows within OREIS metadata and codes tables

\begin{tabular}{lc}
\hline \multicolumn{1}{c}{ Tablc } & Number of rows \\
\hline ALIAS_SOURCE & 0 \\
CODE & 644 \\
CONTACT & 0 \\
CRITERIA & 31 \\
DATASET & 3 \\
DATA_DICT & 768 \\
METHOD & 108 \\
METHOD_TYPE & 0 \\
PARAMETER & 1,148 \\
TRANSMITTAL & 37 \\
Total & 2,739 \\
\hline
\end{tabular}


Table 4. Dates associated with data packages transmitted to OREIS

\begin{tabular}{|c|c|c|c|c|c|c|}
\hline Data set & $\begin{array}{l}\text { Received from } \\
\text { project }\end{array}$ & $\begin{array}{l}\text { Sent to DOE, } \\
\text { EPA, and TDEC }\end{array}$ & $\begin{array}{l}\text { Processed and } \\
\text { reviewed }\end{array}$ & $\begin{array}{l}\text { Loaded into } \\
\text { OREIS }\end{array}$ & $\begin{array}{l}\text { Authorizod for } \\
\text { nelease }\end{array}$ & Reference \\
\hline WAG 6 & $1 / 30 / 92$ & $\begin{array}{l}2 / 28 / 92 \\
3 / 19 / 92\end{array}$ & & & & ES/ER-22/V5\&D1, ORNL/ER/Sub-87/99053/5/V5 ${ }^{b}$ \\
\hline CR OU 2 (FCAP) & $2 / 4 / 92$ & $\begin{array}{l}2 / 13 / 92 \\
3 / 19 / 92\end{array}$ & $10 / 15 / 93$ & $10 / 15 / 93$ & & ES/ER-23\&D1, Y/ER/Sub-90/977777/2 \\
\hline K1407 OU (B\&C Ponds) & $\begin{array}{c}4 / 30 / 92 \\
9 / 3 / 92\end{array}$ & $9 / 22 / 92$ & $10 / 8 / 93$ & $10 / 8 / 93$ & & DOE/OR-1012\&D3 ${ }^{d}$ \\
\hline WAG 1 - soils & $11 / 5 / 92$ & $11 / 30 / 92$ & $10 / 29 / 93$ & $10 / 29 / 93$ & & DOE/OR-1043/V3\&D1 $1^{e}$ \\
\hline WAG 1 - other & $11 / 5 / 92$ & $11 / 30 / 92$ & & & & $\begin{array}{l}\text { DOE/OR-1043/V1\&D1 } 1^{e} \\
\text { DOE/OR-1043/V2\&D1 } 1^{e} \\
\text { DOE/OR-1043/V4\&D1 }\end{array}$ \\
\hline Clinch River & $\begin{array}{c}11 / 1 / 92 \\
11 / 24 / 92\end{array}$ & $11 / 25 / 92$ & & & & ORNL/ER-155 \\
\hline LEFPC & $4 / 29 / 93$ & $5 / 26 / 93$ & & & & DOE/OR/02-1119\&D2\&V6 $6^{8}$ \\
\hline BSCP 1 & $6 / 16 / 93$ & & & & & DOE/OR/01-1136h \\
\hline
\end{tabular}

${ }^{a}$ EPA = Environmental Protection Agency; TDEC = Tennessee Department of Environment and Conservation.

${ }^{b}$ RCRA Facility Investigation Repon for Waste Area Grouping 6 at Oak Ridge National Laboratory, Oak Ridge, Tennessee, ES/ER-22/V5\&D1, ORNL/ER/Sub-87/99053/5/V5 (Energy Systems 1991a).

'Remedial Investigation Report for Chestnut Ridge OU2 (Filled Coal Ash Pond) at the Oak Ridge Y-12 Plant, Oak Ridge, Tennessee, ES/ER-23\&D1, Y/ER/Sub-90/977777/2 (Energy Systems 1991b).

${ }^{d}$ Remedial Investigation/Feasibility Study for the K-1407-B/C Ponds, DOE/OR-1012\&D3 (DOE 1992b).

eSite Characterization Summary Report for Waste Area Grouping 1 at Oak Ridge National Laboratony, DOE/OR-1043/V1-V4\&D1 (DOE 1992c).

fPhase I Data Summary Report for the Clinch River Remedial Investigation Health Risk and Ecological Risk Screening Assessment, ORNL/ER-155 (Energy Systems 1992).

sLower East Fork Poplar Creek-Sewer Line Beltway Remedial Investigation Report, DOE/OR/02-1119\&D2\&V6 (DOE 1994).

hAnnual Report on the Background Soil Characterization Project on the Oak Ridge Reservation, Oak Ridge, Tennessee-Results of Phase 1 Investigation, DOE/OR/01-1136 (DOE 1993a). 
Table 5. Descriptions of data packages transmitted to OREIS

\begin{tabular}{|c|c|c|c|}
\hline Data set & TRANS_IDs & $\begin{array}{l}\text { Number of } \\
\text { rows in IFF }\end{array}$ & Description \\
\hline WAG 6 & 11,25 & 77,196 & $\begin{array}{l}\text { ORNL, WAG } 6 \text { (area west of the laboratory): Remedial Investigation (RI) to } \\
\text { examine potential radioactive contamination in groundwater from burial of low- } \\
\text { level wastes }\end{array}$ \\
\hline CR OU 2 (FCAP) & 8 & 1,673 & $\begin{array}{l}\text { Y-12, Chestnut Ridge OU 2, Filled Coal Ash Pond: RI to examine potential } \\
\text { leachates from coal slurry }\end{array}$ \\
\hline K1407 OU (B\&C Ponds) & 9 & 8,519 & $\begin{array}{l}\text { K-25, K1407, B \& C Ponds: RI to check for residual contamination after non- } \\
\text { radioactive sludge was removed from the two settling ponds }\end{array}$ \\
\hline WAG 1 - soils & 10 & 73,649 & $\begin{array}{l}\text { ORNL, WAG } 1 \text { (main laboratory area): RI looking at a variety of groundwater, } \\
\text { surface water, soil, sludge, etc. problems associated with tanks, ponds, and other } \\
\text { pollutant sources }\end{array}$ \\
\hline WAG 1 - other & $\begin{array}{l}13,14,21,24 \\
35,36\end{array}$ & 64,735 & Same as WAG 1 soils described above \\
\hline Clinch River & 12 & 44,130 & $\begin{array}{l}\text { Off Site, Clinch River and Watts Bar: Study of radioactive contamination in the } \\
\text { sediment and water }\end{array}$ \\
\hline LEFPC & 15,16 & 104,075 & $\begin{array}{l}\text { Off Site, Lower East Fork Poplar Creek: RI of mercury contamination in soils from } \\
\text { the Y-12 site }\end{array}$ \\
\hline BSCP I & 18 & & $\begin{array}{l}\text { Background Soils Characterization Project, Phase I \& II: Measurements of many of } \\
\text { the contaminants in soils found in other RI studies, but from noncontaminated } \\
\text { background soils. }\end{array}$ \\
\hline Total & & 373,977 & \\
\hline
\end{tabular}

${ }^{a} \mathrm{IFF}=$ Interchange File Format. 


\subsubsection{ORR S-16A Base Map}

To provide a consistent and comprehensive base map for spatial processing and mapping of the measurement data, OREIS manages and maintains the S-16A map data base for the ORR. These data are based on the 1:24,000 scale S-16A map created by the Tennessee Valley Authority (TVA) for the ORR. The base map is maintained in the Oak Ridge Administrative Grid System (feet) and the Tennessee State Plane NAD83 Coordinate System (meters). Each geographic theme within the S-16A data base is comprised of several coverages that have common characteristics. Specific themes include:

- Transportation-such as roads, railroads, and bridges;

- Topography-including elevation contours;

- Hydrology-including rivers, creeks/drains, and ponds;

- Buildings-and other structures;

- Utilities-systems such as transmission lines; and

- Adminbounds-including administrative and political boundaries.

Specific thematic layers, sometimes referred to as coverages, are described in Appendix A. Examples of thematic layers include:

- Roads2-secondary roads;

- 100contour-100-ft contours;

- Shore-shorelines of rivers, lakes, and ponds; and

- Counties-county boundaries.

Further information and metadata on the S-16A and other geographic data bases for the ORR will be provided in Documentation of Oak Ridge Reservation Geographic Data Base, which is currently under development.

\subsubsection{Operable Unit Boundaries}

The Oak Ridge Reservation Site Management Plan for the Environmental Restoration Program (DOE 1993b) describes waste area groupings (WAGs)/OUs, their priorities for characterization and cleanup, and their geographic boundaries. This plan is updated each year. The names and descriptions of each WAG or OU are contained in the OREIS PROJECT table (Appendix B). The boundaries for the WAGs and OUs are stored in the OREIS geographic data base as separate coverages for the three sites, the off-site areas, and the groundwater areas. The boundaries were digitized from maps compiled in collaboration with each site and the ER Program.

\subsubsection{Raster Images}

Background raster images from natural color and color infrared aerial photographs were created for each of the three sites. These photographs were acquired during the April 1992 reservation-wide aerial survey. New digital color orthophotographs are being processed from the April 1993 overflights for the ORR and surrounding area to replace the current imagery.

The characteristics of the image coverages for the ORR and each site are given in Table 6 and their spatial extent shown in Fig. 2. The images are stored in the /share/oreis0/bmoll directory on the OREIS central server. The digital imagery is provided in 
both the Oak Ridge Administrative Grid System (Admin, -adm file extension) and the Tennessee State Plan NAD83 Coordinate System (State Plane, -TSP file extension). Each image data set consists of two ERDAS Version 7.5 files, a .lan containing the image and a sta containing simple statistics, georeferencing, and other information about the imagery. The directory also contains the original ground control point files and the associated coefficient files from which the images were created.

The image processing steps for all images included establishing the ground control points based on the S-16A base map, generating a transformation equation for each image with a minimum root mean square error of less than one pixel, and re-projecting the image into the two coordinate systems using a nonlinear rectification program. A third-order projection fit was necessary on the ORR image because of the high amount of relief. Finally, the S-16A vector base map was overlaid on the images as a quality assurance check.

Table 6. Description of the OREIS raster images for the ORR sites

\begin{tabular}{|c|c|c|c|}
\hline Site & Pixel size & Projection & Description \\
\hline ORR & $15 \mathrm{ft}$ (Admin) & $\begin{array}{l}\text { Admin, State } \\
\text { Plane }\end{array}$ & $\begin{array}{l}\text { Orthophotographic mosaic from natural color photographs flown at } \\
6000 \text { ft above ground level (AGL) }\end{array}$ \\
\hline ORNL & $10 \mathrm{ft}$ (Admin) & $\begin{array}{l}\text { Admin, State } \\
\text { Plane }\end{array}$ & $\begin{array}{l}\text { Orthophotographic mosaic from } 19 \text { scanned color photographs flown at } \\
3000 \mathrm{ft} \text { AGL with additional warping to minimize feature mismatch } \\
\text { across joins }\end{array}$ \\
\hline $\mathrm{K} 25$ & $10 \mathrm{ft}$ (Admin) & $\begin{array}{l}\text { Admin, State } \\
\text { Plane }\end{array}$ & $\begin{array}{l}\text { Orthophotograph from a single, scanned, natural color photograph } \\
\text { flown at } 9,500 \text { ft } \mathrm{AGL}\end{array}$ \\
\hline $\mathbf{Y 1 2}$ & $10 \mathrm{ft}$ (Admin) & $\begin{array}{l}\text { Admin, State } \\
\text { Plane }\end{array}$ & $\begin{array}{l}\text { Orthophotographic mosaic from four scanned, natural color } \\
\text { photographs flown at } 6000 \mathrm{ft} A G \mathrm{~A} \text {, rewrapped to improve feature } \\
\text { matching control across boundaries }\end{array}$ \\
\hline
\end{tabular}

\subsubsection{Points}

The locations of sampling stations were created directly from the OREIS LOCATION table by converting a copy of this table to an ARC/NFO data file. User-supplied easting and northing coordinates were used to generate an ARC/INFO point coverage in the userspecified local grid system. The point coverage was converted to the Oak Ridge Administrative Grid System and to the State Plane Coordinate System using the TORC: $A$ Computer Program for the Transformation of Oak Ridge Coordinates (in press). New points were appended to the ORR-wide point coverages in both Administrative and State Plane grid systems. The ARC/INFO coverage names are LOCATION_ADMIN and LOCATION_SP, respectively. Each coverage has LOCATION_ID as an attribute that links to the LOCATION_ID field in the ORACLE LOCATION table. The State Plane coverage was used to generate latitude and longitude coordinates for each point. Eastings and northings in Administrative Grid System along with latitude and longitude coordinates were transferred back to the ORACLE LOCATION table. There are currently 1177 points defined in the ORR-wide coverage (Fig. 3). 


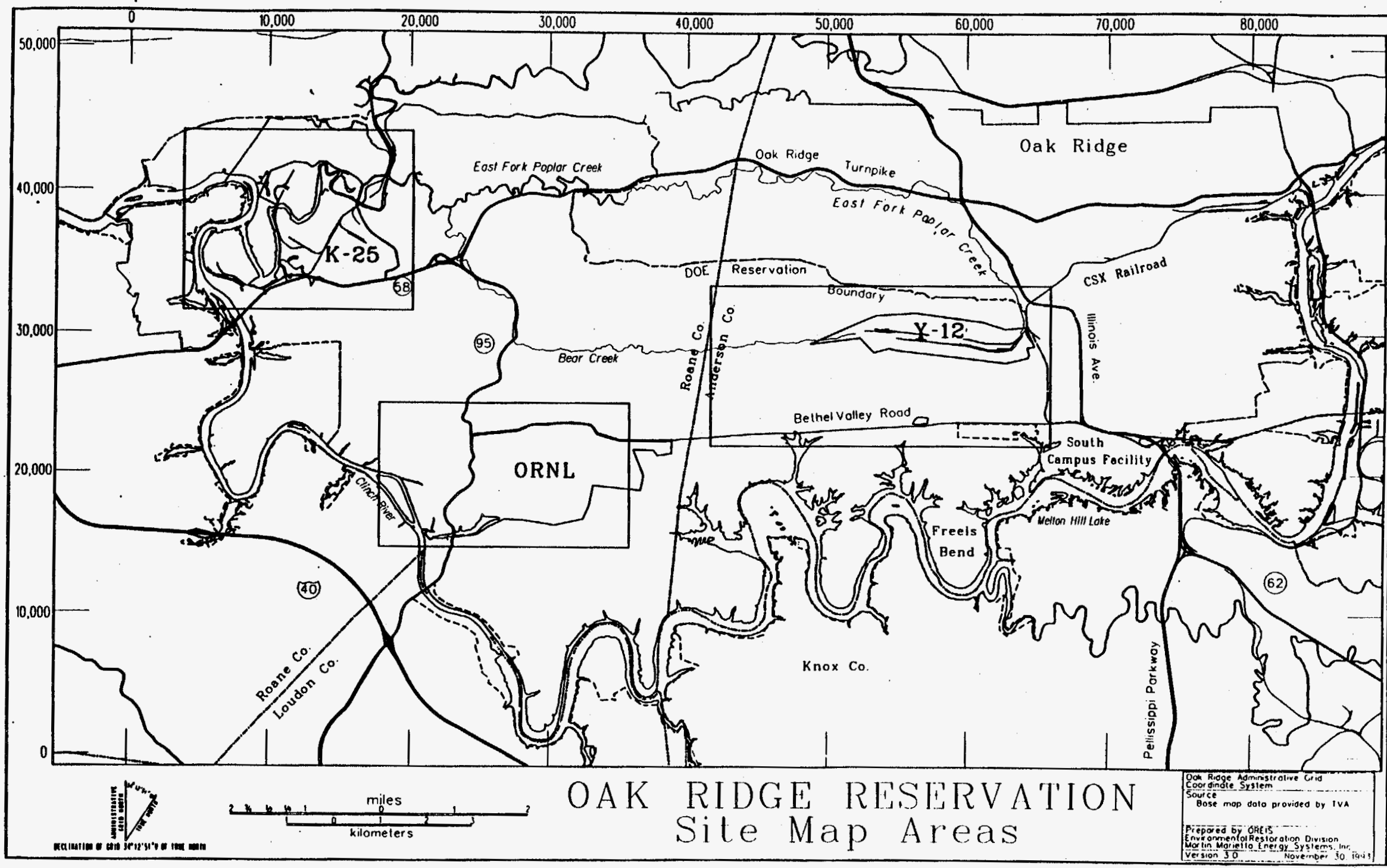

Fig. 2. Index map of the raster image coveragcs. 


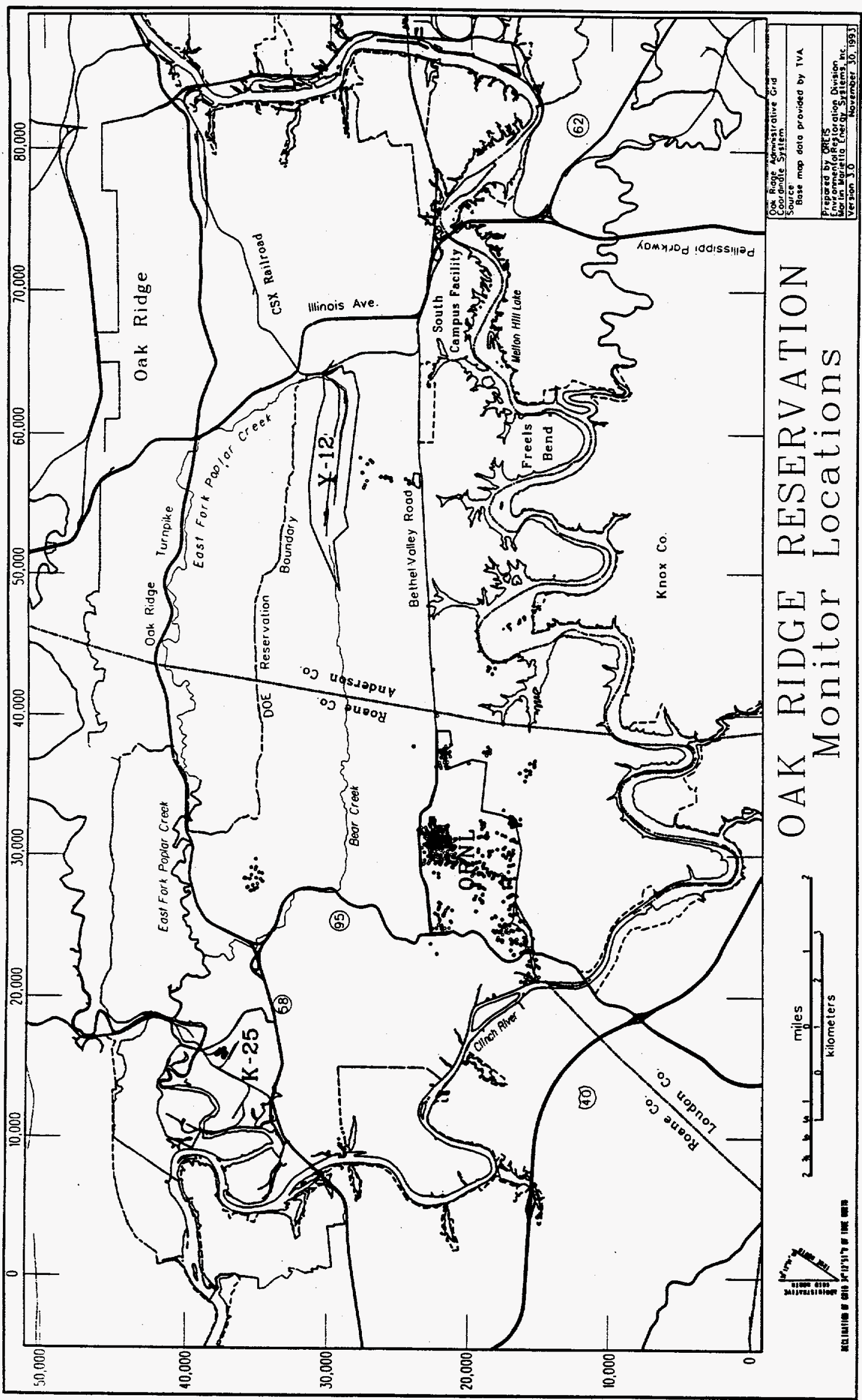

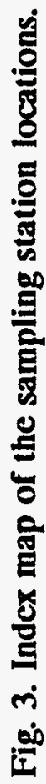




\section{REFERENCES}

DOE (U.S. Department of Energy). 1994. Lower East Fork Poplar Creek-Sewer Line Beltway Remedial Investigation Report, DOE/OR/02-1119\&D2\&V6, prepared by Science Applications International, Oak Ridge, Tennessee, January.

DOE (U.S. Department of Energy). 1993a. Annual Report on the Background Soil Characterization Project on the Oak Ridge Resenvation, Oak Ridge, Tennessee-Results of Phase 1 Investigation, DOE/OR/01-1136, prepared by Martin Marietta Energy Systems, Inc., Oak Ridge, Tennessee, May.

DOE (U.S. Department of Energy). 1993b. Oak Ridge Resenvation Site Management Plan for the Environmental Restoration Program, DOE/OR-1001/R3, Environmental Restoration Division, U.S. Department of Energy, Oak Ridge, Tennessee, November.

DOE (U.S. Department of Energy). 1992a. Federal Facility Agreement for the Oak Ridge Reservation, DOE/OR-1014, U.S. EPA-Region IV, U.S. DOE, and Tennessee Department of Environment and Conservation, January 1.

DOE (U.S. Department of Energy): 1992b. Remedial Investigation/Feasibility Study for the $K-1407-B / C$ Ponds, DOE/OR-1012\&D3, prepared by Martin Marietta Energy Systems, Inc., Oak Ridge K-25 Site, Oak Ridge, Tennessee, December.

DOE (U.S. Department of Energy). 1992c. Site Characterization Summary Report for Waste Area Grouping 1 at Oak Ridge National Laboratory, DOE/OR-1043/V1-V4\&D1, prepared by Martin Marietta Energy Systems, Inc., Oak Ridge, Tennessee, September.

Energy Systems (Martin Marietta Energy Systems, Inc.). 1992. Phase I Data Summary Report for the Clinch River Remedial Investigation Health Risk and Ecological Risk Screening Assessment, ORNL/ER-155, Oak Ridge, Tennessee.

Energy Systems (Martin Marietta Energy Systems, Inc.). 1991a. RCRA Facility Investigation Report for Waste Area Grouping 6 at Oak Ridge National Laboratory, Oak Ridge, Tennessee, ES/ER-22/V5\&D1, ORNL/ER/Sub-87/99053/5/V5, Oak Ridge, Tennessee, September.

Energy Systems (Martin Marietta Energy Systems, Inc.). 1991b. Remedial Investigation Report for Chestnut Ridge OU2 (Filled Coal Ash Pond) at the Oak Ridge Y-12 Plant, Oak Ridge, Tennessee, ES/ER-23\&D1, Y/ER/Sub-90/977777/2, prepared by CH2M Hill, Oak Ridge, Tennessee, December.

TOA. 1991. State Oversight Agreement between the State of Tennessee and the Department of Energy, effective date: May 13. 

Appendix A

Oak Ridge Environmental Information System Geographic Data Base 



\section{General Data Base Information}

Database Name:

Path:

Description:

Arca Covered:

Map Scale:

Software/Format:

Last Update:

Contact Pcrson:

Telephone:
OREIS Geographic Data (vector)

/share/oreis_data/gis/vector/admin or

/share/oreis_data/gis/vector/sp_83

The data base consists of two data files: the S-16A Map Data base for the ORR, compiled by TVA, and the ORR Operable Units. Both data files are maintained in the Oak Ridge Administrative Grid Coordinate System and in Tennessee State Plane, NAD83.

The DOE Oak Ridge Reservation and surrounding areas $1: 24,000$

Arc/Info

Sept. 30, 1993

Fred E. Latham

(615) 574-5393

\section{Cartographic Information}

Gcographic Extent: Data extent -9.8 miles by 17.9 miles

Data set boundary -

Admin. Grid Northings: (-784 to $51,088 \mathrm{ft})$

Admin. Grid Eastings: $(-5,107$ to $89,349 \mathrm{ft})$

$\begin{array}{ll} & \text { Geographic size }-175 \mathrm{mi}^{2} \text {, or 112,479.8 acres } \\ \text { Map Projection: } & \text { Oak Ridge Administrative Grid (Admin Grid) }\end{array}$

Tennessee State Plane (Tenn State Plane)

Projection Units:

Admin Grid is feet

Tenn State Plane is meters

Vertical Datum:

Admin Grid is National Geodetic Vertical Datum 1929

Tenn State plane is National Geodetic Vertical Datum 1988

Horizontal Datum: Admin Grid is North American Datum (NAD)27

Tenn State Plane is NAD83

\section{Theme Information for S-16A}

buildings

path: /share/oreis_data/gis/vector/admin/s16av2.0/buildings or /share/oreis_data/gis/vector/sp_83/s16av2.0/buildings

layer name: description:

bldg1 houses, apartments, offices

barns barns, storage sheds

publicbldgs churches, schools

transportation

path: /share/oreis_data/gis/vector/admin/s16av2.0/transportation or /share/oreis_data/gis/vector/sp_83/s16av2.0/transportation 
layer name:

description:

roads1

roads2

primary roads, interstates, state highways

roads 3

roads 4

trails

rractive

rrinactive

bridges

dams secondary roads (i.e., Bethel Valley $R d$ ) tertiary roads, city streets jeep roads

trails

active railroads

inactive railroads

bridges, tunnels, all in eastern $1 / 3$ of map masonry dams

utilitics

path: /share/oreis_data/gis/vector/admin/s16av2.0/utilities or /share/oreis_data/gis/vector/sp_83/s16av2.0/utilities

layer name: description:

tlines electric transmission lines

pipelines above ground pipelines

substations substations

\section{topography}

path: /share/oreis_data/gis/vector/admin/s16av2.0/topography or /share/oreis_data/gis/vector/sp_83/s16av2.0/topography

layer name: description:

20contours 20-ft contours

100 contours $\quad 100$-ft contours

hydrology

path: /share/oreis_data/gis/vector/admin/s16av2.0/hydrology or

/share/oreis_data/gis/vector/sp_83/s16av2.0/hydrology

layer name: description:

drains creeks, single line drains

ponds tailing ponds

rivmarks(50) river mile markers

shore rivers, lakes, and ponds

adminbounds

path: /share/oreis_data/gis/vector/admin/s16av2.0/adminbounds or

/share/oreis_data/gis/vector/sp_83/s16av2.0/adminbounds

layer name: description:

doebnd approx DOE reservation boundary

$\underline{\text { misc }}$

path: /share/oreis_data/gis/vector/admin/s16av2.0/misc or

/share/oreis_data/gis/vector/sp_83/s16av2.0/misc

$\begin{array}{ll}\text { layer name: } & \text { description: } \\ \text { tanks(50) } & \text { tanks }\end{array}$




\section{Theme Information for Operable Units}

surfaceous

path: /share/oreis_data/gis/vector/admin/operableunits/surfaceous or

/share/oreis_data/gis/vector/sp_83/operableunits/surfaceous

$\underline{\mathbf{k} 25}$

path: /share/oreis_data/gis/vector/admin/operableunits/surfaceous/k25 or /share/oreis_data/gis/vector/sp_83/operableunits/surfaceous/k25

layer namc: $\quad$ description:

k25ous K-25 operable units

$\underline{12}$

path: /share/oreis_data/gis/vector/admin/operableunits/surfaceous/y12 or

/share/oreis_data/gis/vector/sp_83/operableunits/surfaceous/y12

laycr namc: description:

y12ous Y-12 operable units

ornl

path: /share/oreis_data/gis/vector/admin/operableunits/surfaceous/ornl or /share/oreis_data/gis/vector/sp_83/operableunits/surfaceous/ornl

laycr name: description:

wag1 waste area grouping \# 1

wag2 waste area grouping \# 2

wag3 waste area grouping \# 3

wag4 waste area grouping \# 4

wag5 waste area grouping \# 5

wag6 waste area grouping \# 6

wag7 waste area grouping \# 7

wag8 waste area grouping \# 8

wag9 waste area grouping \# 9

wag10points . waste area grouping \# 10, a point coverage

wag11 waste area grouping \# 11

wag13 waste area grouping \# 13

ouwags concatenation of wags that are operable units; all

of those listed above

offsite

path: /share/oreis_data/gis/vector/admin/operableunits/surfaceous/offsite or /share/oreis_data/gis/vector/sp_83/operableunits/surfaceous/offsite

layer name: description:

fba Freels Bend area operable unit

csX CSX Railroad operable unit

lefpc Lower East Fork Poplar Creek operable unit

sewerline sewerline beltway operable unit

clinchriver Clinch River operable unit

\section{groundwaterous}

path: /share/oreis_data/gis/vector/admin/operableunits/groundwaterous or /share/oreis_data/gis/vector/sp_83/operableunits/groundwaterous 
layer name:

description:

gwous

groundwater operable units

\section{Lineage of the S-16A Map Data Base}

\subsection{Lincage of the S-16A Source Map}

Source map name

Original date

Revision dates

Creator of source

Source descriptions

Issuing agency for source
Oak Ridge S-16A Area Map

1974

Aerial photos 1984

Field checked 1986

Republished 1987

Printed 1988

TVA

U.S. Geological Survey (USGS) benchmarks symbolized on map

TVA

\subsection{Computerization Process by TVA to Create Intergraph Version 1.0}

Description

Date of automation

Automation agency

Contact person

Hardware used

Software

Source media

Quality of media

Digitizing coordinates

Resolution of data

Output transfer format
Vector map features were digitized from mylar separations on Intergraph system from photogrammetrically compiled aerial photos Approximate 1985-1987

TVA

John Cooper, TVA, Chattanooga, Telephone number (615) 751-2246

DEC Vax 750

Intergraph IGDS system

Mylar separations at 1:24,000 map scale

Excellent

Intergraph integer units of resolution

Four Intergraph distance units per meter

SIF (Standard Interchange Format) and DGN

\subsection{Processing History to Creatc GDS Intergraph Version 2.0 of S-16A Digital Data}

Processing procedures

Mathematical algorithms

Procedure parameters

Resulting grid system

Procedure date

Procedure contact

Processing hardware

Software used

Accuracy statistics
Working unit conversion, conversion to Administrative Grid, section merging, edits to geographic objects and breaking out objects on certain layers (see Section 4)

Affine least square fit for coordinate conversion Used known benchmarks and control points supplied with TVA original Intergraph file Administrative Grid in feet Approximate 1992-1993

Ed A. Bright, ORNL

Telephone (615) 574-5430

Intergraph Clipper Unix Workstation Microstation, Microstation Projection Manager RMS error $2.46 \times 10^{-9}$ 
Source for updates

Revision status

Objects edited
S-16A paper map

Ongoing (see Sect. 4)

All objects converted to Administrative Grid, see Sect. 4 for details on editing

\subsection{Quality Assurance Measures and Characteristics}

Positional accuracy

Content consistency
$90 \%$ of data on 1:24,000 map are within $1 / 50$ of an inch of actual position on the ground, resulting in error $\leq+$ or $-40 \mathrm{ft}$ meeting USGS National Map Accuracy Standards.

Mylar checkplots are being used to compare edited vector data with source S-16A paper map to verify consistency of layers and locations.

\subsection{Status Information}

Degree of completion

Completion dates
23 layers out of approximately 50 original Intergraph layers have undergone conversion, checking, processing, some editing, and correction. 23 layers completed as of April 1993. 

Appendix B

Environmental Restoration Projects in the OREIS PROJECT Table 
Environmental Restoration projects in the OREIS PROJECT table

\begin{tabular}{llll}
\hline \multicolumn{1}{c}{ Site } & \multicolumn{1}{c}{ Operable unit } & \multicolumn{1}{c}{ Code } & \multicolumn{1}{c}{ Project name } \\
\hline K-25 & K-1004 OU & K-1004 OU & K-1004 OU \\
K-25 & K-1007 OU & K-1007 OU & K-1007 OU \\
K-25 & K-1064 OU & K-1064 OU & K-1064 OU \\
K-25 & K-1070 OU & K-1070 OU & K-1070 OU \\
K-25 & K-1401 OU & K-1401 OU & K-1401 OU \\
K-25 & K-1407 OU & K-1407 OU & K-1407 OU \\
K-25 & K-1410 OU & K-1410 OU & K-1410 OU \\
K-25 & K-1413 OU & K-1413 OU & K-1413 OU \\
K-25 & K-1420 OU & K-1420 OU & K-1420 OU \\
K-25 & K-25 GW OU & K-25 GW OU & K-25 Groundwater OU \\
K-25 & K-29 OU & K-29 OU & K-29 OU \\
K-25 & K-33 OU & K-33 OU & K-33 OU \\
K-25 & K-770 OU & K-770 OU & K-770 OU \\
K-25 & K-901 OU & K-901 OU & K-901 OU \\
OFFSITE & CR LWBR & CR LWBR & Lower Watts Bar Reservoir OU \\
OFFSITE & CR OU & CR OU & Clinch River OU \\
OFFSITE & Freels Bnd & Freels Bnd & Freels Bend Area \\
OFFSITE & LEFPC & LEFPC & Lower East Fork Poplar Creek OU \\
OFFSITE & S Campus & S Campus & South Campus Facility OU \\
ORNL & ORNL GW OU & ORNL GW OU & Oak Ridge National Laboratory Groundwater OU \\
ORNL & ORNL WAG 1 & WAG 1 & Oak Ridge National Laboratory WAG 1 \\
ORNL & ORNL WAG 2 & WAG 2 & Oak Ridge National Laboratory WAG 2 \\
ORNL & ORNL WAG 3 & WAG 3 & Oak Ridge National Laboratory WAG 3 \\
& & &
\end{tabular}


Environmental Restoration projects in the OREIS PROJECT table (continued)

\begin{tabular}{|c|c|c|c|}
\hline Site & Operable unit & Code & Project name \\
\hline ORNL & ORNL WAG 4 & WAG 4 & Oak Ridge National Laboratory WAG 4 \\
\hline ORNL & ORNL WAG 5 & WAG 5 & Oak Ridge National Laboratory WAG 5 \\
\hline ORNL & ORNL WAG 6 & WAG 6 & Oak Ridge National Laboratory WAG 6 \\
\hline ORNL & ORNL WAG 8 & WAG 8 & Oak Ridge National Laboratory WAG 8 \\
\hline ORNL & ORNL WAG 9 & WAG 9 & Oak Ridge National Laboratory WAG 9 \\
\hline ORNL & ORNL WAG10 & WAG 10 & Oak Ridge National Laboratory WAG 10 \\
\hline ORNL & ORNL WAG11 & WAG 11 & Oak Ridge National Laboratory WAG 11 \\
\hline ORNL & ORNL WAG 13 & WAG 13 & Oak Ridge National Laboratory WAG 13 \\
\hline ORNL & WAG 1 OU 1 & WAG 1 OU 1 & WAG 1: Gunite and Associated Tanks OU 1 \\
\hline ORNL & WAG 1 OU 2 & WAG 1 OU 2 & WAG 1: Surface Impoundment OU 2 \\
\hline ORNL & WAG 1 OU 3 & WAG 1 OU 3 & WAG 1: Underground Piping and Storm Drains OU 3 \\
\hline ORNL & WAG 1 OU 4 & WAG 1 OU 4 & WAG 1: Groundwater OU 4 \\
\hline ORNL & WAG 1 OU 5 & WAG 1 OU 5 & WAG 1: White Oak Creck Floodplain Soils and Sediments OU 5 \\
\hline ORNL & WAG 1 OU 6 & SWSA 1 & WAG 1: Solid Waste Storage Area 1 OU 6 \\
\hline ORNL & WAG 1 OU 7 & SWSA 2 & WAG 1: Solid Waste Storage Area 2 OU 7 \\
\hline ORNL & WAG 1 OU 8 & WAG 1 OU 8 & WAG 1: Waste Pile OU 8 \\
\hline ORNL & WAG 1 OU 9 & WAG 1 OU 9 & WAG 1: Contaminated Soils OU 9 \\
\hline ORNL & WAG 1 OU10 & WAG 1 OU10 & WAG 1: Steel Tank Systems OU 10 \\
\hline ORNL & WAG 2 OU 1 & WAG 2 OU 1 & WAG 2: White Oak Creek Embayment/Tributaries/Soil OU 1 \\
\hline ORNL & WAG 2 OU 2 & WAG 2 OU 2 & WAG 2: Groundwater OU 2 \\
\hline ORNL & WAG 7 OU 1 & WAG 7 OU 1 & WAG 7: Subsurface Disposal OU 1 \\
\hline ORNL & WAG 7 OU 2 & WAG 7 OU 2 & WAG 7: Pipeline \& Leak Site OU 2 \\
\hline
\end{tabular}


Environmental Restoration projects in the OREIS PROJECT table (continued)

\begin{tabular}{|c|c|c|c|}
\hline Site & Operable unit & Code & Project name \\
\hline ORNL & WAG10 OU 1 & WAG 10 OU 1 & WAG 10: Grout Sheets OU 1 \\
\hline ORNL & WAG10 OU 2 & WAG 10 OU 2 & WAG 10: Deep Groundwater OU 2 \\
\hline ORNL & WAG10 OU 3 & WAG 10 OU 3 & WAG 10: Hydrofracture Wells Plugging \& Abandonment OU 3 \\
\hline $\mathrm{Y}-12$ & $\mathrm{BC}$ OU 1 & $\mathrm{BC}$ OU 1 & Bear Creek OU 1 \\
\hline $\mathrm{Y}-12$ & BC OU 2 & BC OU 2 & Bear Creek OU 2 \\
\hline$Y-12$ & $\mathrm{BC}$ OU 3 & BC OU 3 & Bear Creek OU 3 \\
\hline$Y-12$ & $\mathrm{BC}$ OU 4 & $\mathrm{BC}$ OU 4 & Bear Creek OU 4 \\
\hline Y-12 & CR OU 1 & CR OU 1 & Chestnut Ridge OU 1 \\
\hline $\mathrm{Y}-12$ & CR OU 2 & FCAP & Chesinut Ridge OU 2 \\
\hline $\mathrm{Y}-12$ & CR OU 3 & CR OU 3 & Chestnut Ridge OU 3 \\
\hline$Y-12$ & CR OU 4 & CR OU 4 & Chestnut Ridge OU 4 \\
\hline Y-12 & UEFPC OU 1 & UEFPC OU 1 & Upper East Fork Poplar Creek OU 1 \\
\hline $\mathrm{Y}-12$ & UEFPC OU 2 & UEFPC OU 2 & Upper East Fork Poplar Creek OU 2 \\
\hline $\mathrm{Y}-12$ & UEFPC OU 3 & UEFPC OU 3 & Upper East Fork Poplar Creck OU 3 \\
\hline
\end{tabular}

Source: Oak Ridge Reservation Site Management Plan for the Environmental Restoration Program, DOE/OR-1001/R3, (DOE 1993b). 


\section{DISTRIBUTION}

1. H. L Boston

2. K. W. Cook

3. E. L. Hannahs

4-6. D. M. Matteo

7-8. P. T. Owen

9. P. A. Schrandt

10. J. K. Thomas

11. P. S. Wood

12-46. OREIS Office

47. ORNL ER Document Management Center

48. Central ER Document Management Center

49. Laboratory Records Department

50. ORNL Patent Section

51. Central Research Library

52. G. W. Bodenstein, DOE Oak Ridge Operations Office, P.O. Box 2001, Oak Ridge, TN 37831-8541

53. T. Perry, DOE Oak Ridge Operations Office, P.O. Box 2001, Oak Ridge, TN 37831-8541

54. Office of Assistant Manager for Energy Research and Development, DOE Oak Ridge Operations Office, P.O. Box 2001, Oak Ridge, TN 37831-8600

55-56. Office of Scientific and Technical Information, P.O. Box 62, Oak Ridge, TN 37831 